\title{
Comparison of concentrate feeds with different levels of SynerMax® inclusion for dairy cows ${ }^{1}$
}

\author{
Paul F. Randel ${ }^{2}$
}

J. Agric. Univ. P.R. 89(1-2):51-58 (2005)

\begin{abstract}
Sixteen Holstein and Brown Swiss cows, $112 \pm \mathbf{4 5}$ days in milk, were assigned by stage of lactation to a replicated $4 \times 4$ latin square experimental design with three-week periods. Treatments $A, B, C$ and $D$ were based on pelleted concentrates (CT), theoretically equal in contents of nitrogen (18.0 to $18.3 \%$ crude protection) and energy $(2.6 \mathrm{Mcal} \mathrm{NEL} / \mathrm{kg})$ and containing, respectively, 0, 2, 4 and $8 \%$ of SynerMax $\otimes^{3}$ (coproduct of antibiotic production). These were fed at a rate of $1 \mathrm{~kg} \mathrm{CT} / 2 \mathrm{~kg}$ milk (recalculated weekly) in three daily meals, along with limited access to long hay and nighttime grazing at four cows per hectare on unfertilized grass swards. Mean results for $A$ through $D$ were, respectively: daily CT intake, 10.64, 10.84, 10.25 and 10.57 kg; daily milk yield, 21.32, 21.91, 21.63 and $20.97 \mathrm{~kg}$; milk fat content, 2.76, $2.75,2.52$ and $2.76 \%$; protein content, $3.06,3.02,3.02$ and $3.04 \%$; ratio of milk to $\mathrm{CT}(\mathrm{M} / \mathrm{CT}), 2.01,2.02,2.11$ and 1.98. Significantly different were the higher CT intake with $2 \%$ SynerMax@ (B) vs. $4 \%$ and $8 \%$ (C + D) $(0.43 \mathbf{~ k g ~ d i f - ~}$ ference, $P<0.05$ ), and the higher M/CT with $4 \%$ than with $8 \%$ SynerMax@ (C vs. D) $(0.13 \mathrm{~kg}$ difference, $P<\mathbf{0 . 0 1})$. Incorporation of SynerMax at levels of 2 and $4 \%$ in pelleted CT assured good animal acceptance and had no adverse effects on lactational performance.
\end{abstract}

Key words: fermentation product, pelleted concentrates, feed efficiency, milk production

\section{RESUMEN}

Comparación de alimentos concentrados con diferentes niveles de inclusión de SynerMax® para vacas lecheras

Dieciséis vacas Holstein y Pardo Suiza, $112 \pm 45$ días lactando, se asignaron por etapa de lactación a un diseño experimental de cuadrado latino 4 $\times 4$ repetido, con períodos experimentales de tres semanas. Los tratamientos $A, B, C$ y $D$ se basaron en alimentos concentrados (AC) aperdigonados, teóricamente isonitrogenados ( 18.0 a $18.3 \%$ proteína bruta) e isocalóricos (1.6 Mcal ENL/kg), que incluyeron, respectivamente, $0,2,4$ y $8 \%$ de SynerMax@ (coproducto de la industria farmacéutica). Estos se suplieron a razón de $1 \mathrm{~kg} \mathrm{AC} / 2 \mathrm{~kg}$ leche (recalculado semanalmente) en tres porciones diarias, junto con acceso limitado a heno entero y pastoreo nocturno con carga de cuatro vacas por hectárea en gramíneas no fertilizadas. Las medias

${ }^{1}$ Manuscript submitted to Editorial Board 25 February 2004.

${ }^{2}$ Researcher, Animal Industry Department. Agricultural Experiment Station, HC-01

Box 11656, Lajas, PR 00667.

sTrade name used only to provide specific information. 
de los resultados de $A$ a $D$ fueron respectivamente: consumo diario de $A C$, $10.64,10.84,10.25$ y $10.57 \mathrm{~kg}$; producción diaria de leche, $21.32,21.91,21.63$ y $20.97 \mathrm{~kg}$; contenido de grasa en la leche, $2.76,2.75,2.52$ y $2.76 \%$; contenido de proteína, 3.06, 3.02, 3.02 y 3.04\%; y proporción de leche a AC (L/ $\mathrm{AC}), 2.01,2.02,2.11$ y 1.98. Se verificó significación en el mayor consumo de concentrado para $2 \%$ SynerMax $(B)$ sobre $4 \%$ y $8 \%(C+D)(0.43 \mathrm{~kg}$ diferencia, $P<0.05$ ), y en la mayor $L / A C$ con $4 \%$ que con $8 \%$ SynerMax $\otimes$ (C vs. D) ( $0.13 \mathrm{~kg}$ diferencia, $\mathrm{P}<\mathbf{0 . 0 1})$ La incorporación de SynerMax en los AC aperdigonados a niveles de hasta $4 \%$ aseguró la buena aceptación animal y no afectó el desempeño lactante.

Palabras clave: producto de fermentación, concentrados aperdigonados, producción de leche, eficiencia alimentaria

\section{INTRODUCTION}

The liquid feedstuff called SynerMax® is an industrial coproduct of antibiotic production at the operations of Abbott Laboratories in North Chicago, Illinois, and Barceloneta, Puerto Rico. It consists of the spent culture remaining after fermentation and extraction of the antibiotic, including residues of streptomyces. This remaining culture is subjected to enzyme treatment and condensation. Local production of this improved coproduct began in 2001 and replaced the former less concentrated byproduct known as liquid streptomyces solubles (LSS). Both of these liquid feeds have had beneficial effects in poultry feeding beyond their energy and protein contents; these beneficial effects are ascribed to unidentified fermentation factors (Abbott Laboratories, 1996; Fidler et al., 2002; Kidd et al., 2002). The producing company is interested in determining whether such a synergistic effect might also occur when SynerMax ${ }^{\circledR}$ is fed to lactating dairy cows. In a previous experiment (Randel and Moyá, 2003), feeding of SynerMax®in an 85:15 mixture with cane molasses, offered free choice to dairy cows, resulted in milk production equal to that of the control without liquid supplement (but with a correspondingly higher intake of solid concentrates); however, no synergistic effect of the coproduct was detected. The present experiment was undertaken to test three levels of SynerMax® inclusion in pelleted concentrates for dairy cows versus a control, evaluating the effects of this alternative mode of utilization on milk production and feed efficiency.

\section{MATERIALS AND METHODS}

The experiment was conducted at the Lajas Agricultural Experiment Station from November to February, using 16 Holstein and Brown Swiss cows ranging in days postpartum from 45 to 185 (mean $112 \pm 45, \mathrm{SD}$ ). The 16 cows were assigned to four quartets according to stage of lactation; mean days postpartum per quartet was 153, 126, 103 
and 68. Each quartet constituted a square in a replicated latin square experimental design.

Four experimental treatments (A, B, C and D) were based on concentrate feeds containing $0,2,4$ and $8 \%$ SynerMax®, respectively (Table 1). In preparing these formulas, liquid SynerMax® was weighed and slowly poured over the other ingredients in a ribbon-type horizontal mixer; then the mixture was transported to the hopper of a CPM Master Model pellet mill. Because of a malfunctioning boiler, pelleting had to be done in small batches of one-half to one ton, relying on heat generated in the dye without addition of steam. In order to minimize breakage, pelletes were bagged upon exiting the dye and cooled to ambient temperature by natural ventilation.

Individual concentrate allowances were calculated weekly in most cases, or biweekly, according to the ratio $1 \mathrm{~kg}$ concentrate per $2 \mathrm{~kg}$ milk produced. The total daily allowance was divided into three equal portions that were fed to cows in stanchions, the first after morning milking at about $6: 30 \mathrm{~h}$, the second at 10:30 h, and the third following afternoon milking at about 15:00 $\mathrm{h}$. Uneaten concentrates were recovered and weighed. Cows spent the hours between milkings, except for the 10:30 meal, in a spacious unpaved corral, where they had access to the shade of a sheet metal roof, watering trough and hay racks, in which grass hay was placed prior to entry of the animals.

TABLE 1.-Formula and theoretical nutrient composition of the four concentrate mixtures.

\begin{tabular}{lrrrr}
\hline & \multicolumn{4}{c}{ Treatment } \\
\cline { 2 - 5 } & \multicolumn{1}{c}{$\mathrm{A}$} & $\mathrm{B}$ & $\mathrm{C}$ & $\mathrm{D}$ \\
\hline Ingredient formula (\%) & & & & \\
$\quad$ Ground maize & 48.50 & 46.60 & 45.20 & 44.20 \\
Wheat middlings & 30.00 & 30.00 & 30.00 & 27.00 \\
Soybean meal & 18.50 & 18.50 & 18.00 & 18.50 \\
Ground limestone & 2.40 & 2.40 & 2.40 & 2.10 \\
Salt & 0.50 & 0.40 & 0.30 & 0.10 \\
Premix (vitamin-trace mineral) & 0.10 & 0.10 & 0.10 & 0.10 \\
SynerMax & 0.00 & 2.00 & 4.00 & 8.00 \\
Nutrient composition & & & & \\
Crude protein (\%) & 18.00 & 18.00 & 18.00 & 18.28 \\
Crude fat (\%) & 2.72 & 2.85 & 2.97 & 3.16 \\
Crude fiber (\%) & 4.80 & 4.56 & 4.52 & 4.29 \\
Calcium (\%) & 1.00 & 1.00 & 1.00 & 0.90 \\
Phosphorus (\%) & 0.52 & 0.52 & 0.51 & 0.50 \\
Net energy (lactation) (Mcal/kg) ${ }^{1}$ & 1.62 & 1.61 & 1.60 & 1.60 \\
\hline 1Based tabular values of $\mathrm{NRC}(1988)$ & & & &
\end{tabular}

${ }^{1}$ Based on tabular values of NRC (1988). 
After the 15:00 meal, all the experimental cows were placed together in pasture apart from the rest of the herd until the next morning milking. Rotational grazing took place in four 1-ha paddocks (equivalent to a stocking rate of four animals per hectare). In the 24-day grazing cycles, each paddock was exposed to six days of grazing and then rested for 18 days. The swards were of heterogeneous grass species and received no fertilizer or irrigation. At the outset of this study pasture herbage was subjectively judged adequate for part-time grazing of dairy cows intensively supplemented with concentrates. Thereafter, herbage conditions declined during the first weeks, then benefited from rains in December, but declined again until the end of the experiment in early February while precipitation was minimal. A situation of pasture deficiency existed at the end of the experiment.

Milk samples were taken from four consecutive milkings of individual cows once during each experimental period. Samples of each milking were analyzed separately for contents of fat and protein at the DHI Laboratory of Puerto Rico. Liveweights of the cows were estimated from thoracic perimeter measurement once each month, November, December and January.

The experimental design was a $4 \times 4$ latin square replicated four times. Treatment sequences were balanced within each square but differed among squares. The three-week experimental periods included one week for adjustment and two weeks for comparison of treatments. Data were subjected to analysis of variance with animals, periods and treatments as the three factors and 42 degrees of freedom (df) associated with the error variance. The three df for treatments were used for orthogonal contrasts to compare (1) A vs. B + C + D (control without SynerMax $®$ against all concentrates with SynerMax $®$ combined, 0 vs. $2 \%+4 \%+8 \%$ ); (2) B vs. C + D (lowest level of SynerMax® against two higher levels combined, $2 \%$ vs. $4 \%+8 \%$ ); (3) C vs. D (second highest against highest level, $4 \%$ vs. $8 \%$ ).

\section{RESULTS AND DISCUSSION}

Mean estimated liveweight of the 16 cows, based on three measurements, was $530 \pm 54 \mathrm{~kg}$ (SD). This weight represents typical body size of lactating animals in the herd. Overall mean daily concentrate consumption was $10.6 \mathrm{~kg}$ (Table 2), which was just equal to $2 \%$ of the animals' mean liveweight. Concentrates containing all three levels of SynerMax® were accepted by the animals without difficulty. Over the full experiment, concentrate B resulted in highest intake $(10.84 \mathrm{~kg})$ and $\mathrm{C}$ the lowest $(10.25 \mathrm{~kg}$ ), all of which represents a maximum difference between two treatment means of $0.59 \mathrm{~kg}$. In the statistical 
TABLE 2.-Means by treatment for each period and over the full experiment of the principal response variables.

\begin{tabular}{|c|c|c|c|c|c|}
\hline \multirow[b]{2}{*}{ Period } & \multicolumn{5}{|c|}{ Treatment } \\
\hline & A & B & $\mathrm{C}$ & $\mathrm{D}$ & All \\
\hline \multicolumn{6}{|c|}{ Daily concentrate intake (kg) } \\
\hline 1 & 10.62 & 10.06 & 10.98 & 10.97 & 10.66 \\
\hline 2 & 9.13 & 11.49 & 9.65 & 11.26 & 10.38 \\
\hline 3 & 12.30 & 10.63 & 10.36 & 10.49 & 10.95 \\
\hline 4 & 10.52 & 11.20 & 10.02 & 9.58 & 10.32 \\
\hline Treat. Mean & 10.64 & 10.84 & 10.25 & 10.57 & 10.58 \\
\hline Std. Error & 0.55 & 0.51 & 0.52 & 0.50 & - \\
\hline \multicolumn{6}{|c|}{ Daily milk production $(\mathrm{kg})$} \\
\hline 1 & 21.60 & 19.92 & 24.62 & 21.82 & 21.99 \\
\hline 2 & 18.98 & 24.18 & 20.10 & 22.60 & 21.46 \\
\hline 3 & 24.72 & 21.70 & 21.38 & 21.90 & 22.42 \\
\hline 4 & 19.98 & 21.85 & 20.42 & 17.55 & 19.95 \\
\hline Treat. mean & 21.32 & 21.91 & 21.63 & 20.97 & 21.46 \\
\hline Std. error & 1.09 & 1.10 & 1.17 & 1.22 & - \\
\hline \multicolumn{6}{|c|}{ Milk fat content $(\%)$} \\
\hline 1 & 2.93 & 3.60 & 2.74 & 3.42 & 3.17 \\
\hline 2 & 3.06 & 2.54 & 3.08 & 3.06 & 2.94 \\
\hline 3 & 2.87 & 2.75 & 2.71 & 2.50 & 2.71 \\
\hline 4 & 2.18 & 2.11 & 1.53 & 2.08 & 1.97 \\
\hline Treat. mean & 2.76 & 2.75 & 2.52 & 2.76 & 2.70 \\
\hline Std. error & 0.19 & 0.21 & 0.18 & 0.21 & - \\
\hline \multicolumn{6}{|c|}{ Milk protein content (\%) } \\
\hline 1 & 3.06 & 3.17 & 2.65 & 2.98 & 2.96 \\
\hline 2 & 2.96 & 2.74 & 3.11 & 2.91 & 2.93 \\
\hline 3 & 3.08 & 3.13 & 3.12 & 3.11 & 3.11 \\
\hline 4 & 3.12 & 3.04 & 3.19 & 3.18 & 3.13 \\
\hline Treat. mean & 3.06 & 3.02 & 3.02 & 3.04 & 3.03 \\
\hline Std. error & 0.05 & 0.06 & 0.06 & 0.06 & - \\
\hline \multicolumn{6}{|c|}{ Milk/Concentrate ratio } \\
\hline 1 & 2.04 & 1.98 & 2.24 & 1.98 & 2.06 \\
\hline 2 & 2.07 & 2.10 & 2.09 & 2.00 & 2.06 \\
\hline 3 & 2.02 & 2.03 & 2.07 & 2.09 & 2.05 \\
\hline 4 & 1.90 & 1.96 & 2.06 & 1.84 & 1.94 \\
\hline Treat. mean & 2.01 & 2.02 & 2.11 & 1.98 & 2.03 \\
\hline Std. error & 0.03 & 0.03 & 0.02 & 0.04 & - \\
\hline
\end{tabular}

analysis of concentrate intake, the variance of treatments approached significance $(\mathrm{P}<0.10)$ and $\mathrm{B}$ surpassed $\mathrm{C}+\mathrm{D}(\mathrm{P}<0.05)$, whereas the other two orthogonal contrasts were not significant (Table 3). In general, the inclusion of SynerMax® in pelleted concentrates at levels of 2 , 4 and $8 \%$ proved to be an effective means to prevent possible problems 


\begin{tabular}{|c|c|c|c|c|c|c|c|}
\hline & \multicolumn{2}{|c|}{ Contrast 1} & \multicolumn{2}{|c|}{ Contrast 2} & \multicolumn{2}{|c|}{ Contrast 3} & \multirow{2}{*}{$\begin{array}{c}\text { Treatment } \\
\text { variance }\end{array}$} \\
\hline & A & $\mathrm{B}+\mathrm{C}+\mathrm{D}$ & B & $\mathrm{C}+\mathrm{D}$ & $\mathrm{C}$ & $\mathrm{D}$ & \\
\hline \multicolumn{8}{|c|}{ Concentrate intake $(\mathrm{kg})$} \\
\hline Means compared & 10.64 & 10.56 & 10.84 & 10.41 & 10.25 & 10.57 & \\
\hline Difference & & 0.12 & & 0.43 & & -0.32 & \\
\hline F value & & $<1$ & & 4.50 & & 1.76 & 2.16 \\
\hline Significance level & & NS & & 0.05 & & NS & 0.10 \\
\hline \multicolumn{8}{|l|}{ Milk production (kg) } \\
\hline Means compared & 21.32 & 21.50 & 21.91 & 21.30 & 21.63 & 20.97 & \\
\hline Difference & & -0.18 & & 0.61 & & 0.66 & \\
\hline F value & & $<1$ & & 3.45 & & 3.03 & 2.28 \\
\hline Significance level & & NS & & 0.10 & & 0.10 & 0.10 \\
\hline \multicolumn{8}{|l|}{ Milk fat $(\%)$} \\
\hline Means compared & 2.76 & 2.68 & 2.75 & 2.64 & 2.52 & 2.76 & \\
\hline Difference & & 0.08 & & 0.11 & & -0.24 & \\
\hline $\mathrm{F}$ value & & $<1$ & & $<1$ & & 2.56 & 1.22 \\
\hline Significance level & & NS & & NS & & NS & NS \\
\hline \multicolumn{8}{|l|}{ Milk protein $(\%)$} \\
\hline Means compared & 3.06 & 3.03 & 3.02 & 3.03 & 3.02 & 3.04 & \\
\hline Difference & & 0.03 & & -0.01 & & -0.02 & \\
\hline $\mathrm{F}$ value & & $<1$ & & $<1$ & & $<1$ & $<1$ \\
\hline Significance level & & NS & & NS & & NS & NS \\
\hline \multicolumn{8}{|c|}{ Milk/Concentrate ratio $(\mathrm{kg} / \mathrm{kg})$} \\
\hline Means compared & 2.01 & 2.04 & 2.02 & 2.04 & 2.11 & 1.98 & \\
\hline Difference & & 0.03 & & 0.02 & & 0.13 & \\
\hline $\mathrm{F}$ value & & 1.43 & & 1.01 & & 20.85 & 7.76 \\
\hline Significance level & & NS & & NS & & 0.01 & 0.01 \\
\hline
\end{tabular}


of variable consumption of this coproduct, which can occur when it is offered in liquid supplements, especially those that contain no molasses, as was seen in previous studies (Randel, 2001; Randel and Moyá, 2003). There was no clear time trend in concentrate intake. After period 1 there was a decrease, then an increase, and finally another decrease in periods 2,3 and 4 (Table 2). Daily hay intake per head by the 16 cows eating together was $2.25,2.35,2.46$ and $2.49 \mathrm{~kg}$ in the four successive periods, giving an overall mean of $2.39 \mathrm{~kg}$. These figures do not represent fully ad libitum intakes, as hay was in short supply, thus making it necessary to sometimes feed less than the animals would have consumed voluntarily.

Milk production overall was close to $21.5 \mathrm{~kg}$ daily (Table 2). Ranking of the treatments in decreasing order was B, C, A and D; the difference between highest and lowest means was $0.94 \mathrm{~kg}$. Statistical analysis showed effects only at the $\mathrm{P}<0.10$ level for the treatment variance and for contrasts $B$ versus $C+D$ and $C$ versus D (Table 3 ). The time trend differed from expectation; milk yield was highest in period 3 . This finding might have been due in part to improved pasture conditions for a brief time following rains in December; also short day length and cool weather at this time may have benefited animal comfort. The drop in production between periods 3 and 4 coincided with worsening grazing conditions and advancing stage of lactation (to as much as nine months in the extreme cases). However, the cows longest in lactation were not necessarily the lowest producers in period 4 , since three that had calved from 7.5 to 9 mo previously were still producing between 21.8 and $22.8 \mathrm{~kg}$ of milk daily.

Milk fat content was generally satisfactory only in period 1 , when the overall mean was $3.03 \%$ (Table 2 ). This percentage slipped below the legal minimum of 3.0 to 2.94 in period 2, declined further to 2.71 in period 3 , and fell precipitously to 1.97 in period 4 , coinciding with poor grazing conditions. Treatments exerted no consistent effects on this variable. Treatment means were nearly identical for A, B and D (2.75 to 2.76), whereas mean for $\mathrm{C}$ was a bit lower (2.52). No significant differences $(\mathrm{P}>0.10)$ were detected (Table 3$)$. Milk protein content was normal throughout the experiment (overall mean $3.03 \%$, Table 2 ). Treatment means varied from only 3.06 to $3.02 \%$ and none of the differences approached significance (Table 3 ). The time trend was toward a gradual, but not very consistent, increase in milk protein percentage.

The ratio of milk produced/concentrate consumed (M/CT) was used as a measure of partial feed efficiency (not taking into account grazed forage and hay). Given that a set M/CT of $2 / 1$ was used to calculate concentrate allowances, variation in this ratio resulted either from concentrates being left uneaten or changes in milk yield after calcula- 
tion of the allowance. Concentrate orts were only a small portion of the total offered; treatment means were 1.4, 1.7, 1.3 and 2.6\% for A through D. Changes in production after calculation of concentrate allowances tended toward higher milk yield in periods 1,2 and 3 , whereas in period 4 this trend was reversed. Mean M/CT values of the four treatments in order were $2.01 \pm 0.03 ; 2.02 \pm 0.03 ; 2.11 \pm 0.02$; and $1.89 \pm 0.04$ (Table 2). The difference between the highest and lowest means (C vs. D) was significant $(\mathrm{P}<0.01)$, whereas the other treatment contrasts were not (Table 3). Thus, it might be tentatively concluded that the $8 \%$ level of SynerMax inclusion in pelleted dairy concentrates is too high for optional feed efficiency, whereas the $4 \%$ level looks promising.

\section{LITERATURE CITED}

Abbott Laboratories, 1996. Streptomyces solids and fermentation solubles. Chemical and Agricultural Products Division, Abbott Laboratories, Inc., North Chicago, IL.

Fidler, D. J., B. George, C. L. Quarles and M. T. Kidd, 2002. Effect of dietary liquid saccharopolyspora soluble concentrate on broiler performance and carcass traits. $23^{\text {rd }}$ Ann. Mtg. Southern Poultry Sci. Soc. (Abstract).

Kidd, M. T., D. J. Fidler, K. B. Koch, B. George and C. L. Quarler, 2002. Impact of liquid saccharopolyspora soluble concentrate on pellet mill throughput and broiler performance. $23^{\text {rd }}$ Ann. Mtg. Southern Poultry Sci. Soc. (Abstract).

National Research Council (NRC), 1988. Nutrient Requirements of Dairy Cattle, $5^{\text {th }}$ ed. National Academy of Science, Washington, DC.

Randel, P. F., 2001. Aceptación por bovinos lecheros de tres alimentos líquidos basados en solubles de estreptomicetos preparados por dos procesos distintos. Mem. XVII Reunión ALPA, La Habana, pp. 628-630.

Randel, P. F. and J. R. Moyá, 2003. A liquid supplement of SynerMax® and cane molasses for lactating dairy cows in semi-confinement. J.Agric. Univ. P.R. 87(3-4):137-147. 